João Paolo Cuenca - Petra Petrač

\title{
Otkrio sam da sam umro
}

Vijest

Otkrio sam da sam umro dok sam pokušavao napisati knjigu. To još nije bila ova knjiga. Živio sam sa suprugom u stanu s pogledom na dvorište, dva kata iznad restorana. Osoblje restorana voljelo se družiti u dvorištu u prizemlju, u onom unutarnjem prostoru od kojeg zgrade oblikuju poliedar izopačene prisnosti. Ondje bi jeli, pušili, pričali na telefon, brbljali. Njihove riječi prolazile su kroz zidove mog doma. Kao da sam bio u Strindbergovu Paklu i slušao glasove koji su ga slijedili po jeftinim pariškim hotelima na zalasku 19. stoljeća. No to je bio Rio de Janeiro i za razliku od švedskog pisca, ja nisam bio lud. Ili sam želio vjerovati da nisam. Budući da su me svako jutro budili glasni razgovori koji mi danju nisu dali raditi, a noću ševiti, često sam se žalio na buku. Kada moji prigovori ne bi urodili plodom, zaurlao bih kroz prozor: „Zašuti, kurvin sine!”. Jedne noći nakon kratke izmjene uvreda, bacio sam na njih prvo što mi je došlo pod ruku: vreću smeća punu pisama. Zauzvrat, na prozor dnevnog boravka bačeno je jaje. Moja žena je plakala. Bjelanjak je i dalje curio po staklu kad su pokupili kuverte i uputili se u najbližu stanicu. Policija me privela tereteći me za prijetnju i napad ili opasno ponašanje, broj policijskog izvješća 014-03595/2011.

Tri dana poslije u 11 ujutro probudio me telefonski poziv. Bila je posljednja subota u travnju 2011.

„Halo.”

„Tko je?”

„Koga trebate?”

„Je li to gospodin João Paulo?”

„Da.”

„João Paulo Vieira Machado de Cue...” glas je oklijevao.

„Cuenca”. 
„Tako je. Sin Marije Terese Vieire Machado i Juana Joséa Cuence?”

„Tko je to?"

„Zovem vas iz V. policijske postaje. Ovdje inspektor Gomes. Preuzeli smo vaš dosje nakon prijave o onoj zbrci s restoranom."

„Da?"

„Izgleda da postoji još jedan zapisnik, od 14.07.2008, na vaše ime.”

„Zapisnik?”

„Znate li o čemu se radi?”

„Iz 2008?”

„Da.”

„Nemam pojma.”

„To je izvješće o vašoj smrti."

„Molim?”

„Potvrda o vašoj smrti. Ovdje piše da ste umrli.”

„Ja nisam mrtav.”

„Poznajete li Cristiane Paixão Ribeiro?”

„Ne.”

„Najbolje bi bilo da dođete u stanicu da to razjasnimo."

„Odmah?"

V. policijska postaja Rio de Janeira nalazi se u niskoj zgradi koja je dio glavne zgrade Civilne policije na aveniji Gomesa Freire, u četvrti Lapa. Okružje čuva arhitektonski pentiment Centra: prozorski okviri, postmodernistički neboderi, art deco ulazna vrata, zgrade u francuskom stilu i višekatnice portugalskog naslijeđa. Mnoge zgrade bile su u raspadnom stanju, kao i ona pokraj postaje, održala se samo fasada, goli prozori što otvaraju put prema nebu i zapušten teren. Kad sam policajcu pokazao dokumente, poveli su me kroz metalne police do inspektorova ureda. 
Svaka od tih polica koje su okruživale stolove i stolce, ostavljajući rijetko koji zid praznim, pripovijedala je priču, a svim je pričama zajedničko bilo nerazumijevanje među ljudskim stvorovima moga grada. Pričama koje su njegovi stanovnici prenosili usmenim putem, a koje su zapisničari bilježili, što je od tog mjesta činilo raskrižje izgubljeno između biblioteke, arhiva i mrtvačnice.

„Vi ste Cuenca, zar ne?”

Inspektor Gomes bio je ćelav, imao je pedesetak godina i preko leđa je nosio opasač za pištolj. U nehajnom pozdravu pružio mi je ruku ne ustajući sa stolca. Atavistički strah koji osjećam u prisustvu profesora, svećenika i policije komadić je osobnosti koji me prati od djetinjstva - nikada se nisam osjećao opušteno ispred predstavnika zakona. Kao da je inspektor naslutio moj poremećaj; nasmijao se poput vlasnika ključeva ćelije. Rekao mi je da sjednem i bacio na stol policijski zapisnik 005-0591/2008, izvješće o prijevozu tijela 042435-1005/2008 i potvrdu o smrti 04331/08 - svi dokumenti su potvrđivali da je João Paulo Vieira Machado de Cuenca, sin Marije Terese Vieire Machado i Juana Joséa Cuence, rodnoga lista pod brojem PED219 4177LV255A, umro.

Gledajući me napola prijeteće, napola znatiželjno, inspektor je promatrao moju reakciju dok sam čitao policijski zapisnik. Zatim je postavio jedno od onih pitanja za koje se nadate da ih nikada nećete čuti: „Gdje ste bili 14.07.2008.?” Pogledao sam u sat na zidu. Bilo je 12:05 - nije radio. Ne znam zašto, no činilo mi se da pokazuje 00:05, a ne podne. Tog sam dana bio u Rimu. Na dan na koji je zabilježena moja smrt uzrokovana lobarnom pneumonijom uz stvaranje mikroapscesa, upalom mozga uz izgledno postojanje cista toxoplazme gondii, edemima i krvarenjima unutar parenhima mozga, u okupiranoj zgradi u Ulici Relação 47, između Ulice Inválidos i Avenije Gomes Freire, nekoliko metara od policijske stanice, bila je promocija mog drugog romana na talijanskom jeziku, Dan Mastroianni, u maloj knjižari del Cinema, u četvrti Trastevere.

U veljači 2008, nakon razvoda, otišao sam iz Ria ne planirajući se vratiti, u uzbuđenju koje je već postalo dio rutine usklađivanja poziva na promocije ili predavanja u inozemstvu sa svaki put sve dužim i besmislenijim putovanjima. To naivno vjerovanje na odlasku - onaj izvorno europski grijeh, grijeh dona Sebastijana, mojih predaka, generacije emigranata i prognanika koji su se poput domina rušili daleko od kuće - sakrivalo je određenu sklonost tuzi, nejasnoj želji da nestanem. Još uvijek nisam bio uvidio da se moja osobnost neće izgraditi gomilanjem iskustava, već da će je to 
izjesti. Nakon susreta pisaca u Portugalu, nekoliko tjedana u Španjolskoj i mjesec dana u Francuskoj, poslije dugog putovanja vlakom, stigao sam u Rim. Osjetio sam onu nejasnu i usamljeničku sreću putnika. Bilo je ljeto, dan je u čitavoj Europi blistao, a ja sam se prisjećao nekoliko golih tijela žena u malom studiju iza zelenih vrata u Ulici Temple 94, u Parizu, i bio sam zaljubljen u jednu od njih. Vratio sam se u Rim promovirati prijevod svoje knjige i bio sam savršen primjer mladoga latinoameričkog pisca gladnog i očaranog iskustvom Europe. Promocija knjige u suton u Trasteveri, zora dočekana na sjedištu motora kojeg je vozila Talijanka pune stražnjice i krivog nosa - možda je to bila neka vrsta vrhunca, vrha planine odakle danas promatram doline i označavam skretanje s puta.

\section{(c) (i) (9)}

Creative Commons Attribution-NonCommercial-NoDerivatives 4.0 International License 